\title{
STRES AKADEMIK DAN GEJALA GASTROINTESTINAL PADA MAHASISWA KEPERAWATAN
}

\author{
Afifah $^{1}$, Ice Yulia Wardani ${ }^{2}$ \\ ${ }^{1}$ Program Studi Sarjana Ilmu Keperawatan, Fakultas Ilmu Keperawatan, Universitas Indonesia \\ ${ }^{2}$ Departemen Keperawatan Jiwa Fakultas Imu Keperawatan, Universitas Indonesia \\ afifah1210@gmail.com
}

\begin{abstract}
ABSTRAK
Salah satu stresor mahasiswa berkaitan dengan akademik. Respon terhadap stres akademik tersebut dapat berupa psikologis dan fisiologis. Salah satu respon fisiologis stres yaitu gejala gastrointestinal. Desain penelitian adalah cross sectional, teknik sampel menggunakan Propotionate stratified random sampling dengan melibatkan 227 mahasiswa. Analisis data menggunakan analisis univariat dan bivariat (uji chi-square). Hasil penelitian menunjukkan bahwa terdapat mahasiswa yang tingkat stresnya tinggi yaitu 44,9\% dan mahasiswa yang mengalami gejala gastrointestinal berat sejumlah $33,5 \%$. Gejala yang banyak dilaporkan yaitu dismotilitas atas diikuti dengan gejala pada usus. Hasil uji korelasi yaitu terdapat hubungan yang signifikan antara stres akademik dengan gejala gastrointestinal pada mahasiswa FIK UI ( $p$ value $=0,018 ;=0,05)$. Hasil uji odd ratio (OR) yaitu 2,037. Hal tersebut berarti mahasiswa dengan stres akademik tingkat tinggi lebih berpeluang mengalami gejala gastrointestinal 2,037 kali dibandingkan dengan mahasiswa yang memilik tingkat stres rendah. Untuk mengurangi tingkat stres akademik seperti ujian, perlu dikembangkan kegiatan diskusi diluar waktu kuliah untuk meningkatkan persiapan.
\end{abstract}

Kata kunci: gejala gastrointestinal, mahasiswa keperawatan, stres akademik

\section{ACADEMIC STRESS AND GASTROINTESTINAL SYMPTOMS IN NURSING STUDENTS}

\begin{abstract}
One of the student stressors is related to academics. The response to academic stress can be psychological and physiological. One of the stressful physiological responses is gastrointestinal symptoms. A cross sectional study design was used, the sample technique using Propotionate stratified random sampling involving 227 students. Data analysis used univariate and bivariate analysis (chisquare test). The results showed that there are students with high stress level that is $44.9 \%$ and students who experience symptoms of gastrointestinal weight of 33.5\%. Most of the nursing student complained of upper dysmotility and bowel symptoms. Correlation test result that there is a significant correlation between academic stress with gastrointestinal symptoms in FIK UI student ( $p$ value = 0,018; = 0,05). Result of odd ratio test (OR) that is 2,037. This means that students with high-level academic stress are more likely to experience gastrointestinal symptoms 2,037 times compared with students who have low levels of stress. To reduce the level of academic stress such as exams, it is necessary to develop discussion activities outside of college time to improve preparation for exams.
\end{abstract}

Keywords: Academic stress, gastrointestinal symptoms, nursing students

\section{PENDAHULUAN}

Mahasiswa memiliki tingkat aktivitas yang tinggi seperti perkuliahan dan kegiatan organisasi. Hal tersebut menyebabkan mahasiswa termasuk komunitas yang rentan mengalami stres. Stres merupakan suatu keadaan yang menjadikan individu merasa mendapatkan tantangan atau perlakuan yang mengganggu kondisi dinamis (Stuart \& Laraia, 2005). Stres yang paling umum dialami mahasiswa adalah stres akademik. Stres akademik merupakan suatu keadaan individu yang mengalami tuntutan akademik yang melampaui sumber daya adaptif yang dimiliki individu (Wilks, 2008). Pada penelitian yang dilakukan oleh Hurst, Baranik, \& Daniel (2012) mengenai mahasiswa yang mengalami stres akademik, didapatkan hasil kejadian stres yaitu $40 \%$ mahasiswa mengalami stres karena proses akademik umum, $20 \%$ mengalami stres karena ujian, $8 \%$ akibat kegiatan dikelas, dan $8 \%$ pada proses belajar. 
Saat ini sudah banyak penelitian mengenai tingkat stres, sumber stres dan respon psikologis pada mahasiswa keperawatan. Namun, penelitian yang membahas respon stres dan dampaknya terhadap respon fisik mahasiswa hanya sedikit, seperti respon stres akademik terhadap gejala gastrointestinal. Gejala gastrointestinal merupakan sekumpulan gejala pada saluran pencernaan dimulai dari mulut, esofagus, lambung, dan usus yang berhubungan dengan kelenjar aksesoris pencernaan (kelenjar saliva, pankreas dan sistem biliari), seperti sakit perut, perut mulas, peningkatan asam lambung, peningkatan flatus, mual, muntah, diare, konstipasi, disfagia, dispepsia, dan anoreksia (Smith \& Watson, 2005).

Berdasarkan penelitian Lee, Mun, Lee, \& Cho (2011) kepada 715 mahasiswa di salah satu akademi keperawatan di Korea didapatkan hasil mahasiswa yang mengalami gejala gastrointestinal sebagai berikut; postpandrial fullness $(91,3 \%)$, kembung $(88,9 \%)$, nyeri perut $(87,8 \%)$ dan diare/konstipasi $(84,7 \%)$ lebih dari 3 bulan. Diantara tanda-tanda diatas yang sering terjadi dan sangat sering terjadi adalah postpandrial fullness $(27,7 \%)$, kembung $(25,8 \%)$, nyeri perut $(17,6 \%)$ dan diare/konstipasi (26,6\%). Dilaporkan bahwa mahasiswa yang memilki lebih dari satu gejala gastrointestinal sebanyak $431 \quad(65 \%)$ mahasiswa. Di antara mereka, 206 (31\%) mahasiswa dilaporkan mempunyai lebih dari tiga gejala gastrointestinal. Secara khusus, 311 $(45,7 \%)$ mahasiswa melaporkan keluhan pada ususnya, $292(39,1 \%)$ mahasiswa melaporkan gejala dismotiliti atas, dan 85 (12,0\%) mahasiswa melaporkan gejala esofagus.

Penyebab gejala gastrointestinal dapat disebabkan oleh banyak faktor. Salah satunya stres. Teori yang mendukung hal itu adalah teori biopsikososial George Engel. Konsep biopsikososial merupakan suatu konsep yang melibatkan interaksi antara faktor biologis, psikologis, dan sosial dalam upaya memahami proses suatu penyakit juga sakitnya seseorang yang memandang pikiran dan tubuh sebagai satu kesatuan. Pendekatan tersebut membawa pengertian bahwa kondisi sakit bukan saja dari segi medis fisik tetapi juga dari kondisi psikologis yang dipengaruhi oleh faktor lingkungan (Waldstein, Shari R, Neumann, Serina A, Drossman, Douglas A, Novack, Dennis H dalam Andri, 2011). Berdasarkan hal tersebut, Penelitian ini mengidentifikasi tingkat stres akademik dan prevalensi gejala gastrointestinal pada mahasiswa yang sehat serta menganalisis apakah terdapat hubungan stres akademik dengan gejala gastrointestinal pada mahasiswa Fakultas Ilmu Keperawatan Universitas Indonesia (FIK UI).

\section{METODE}

Desain penelitian yang digunakan dalam penelitian ini adalah studi ini adalah studi cross sectional. Populasi dan sampel dari penelitian ini merupakan mahasiswa Fakultas Ilmu keperawatan Universitas Indonesia. Pengambilan sampelnya menggunakan teknik propotionate stratified random sampling. Untuk menentukan besar sampel, penelitian ini menggunakan rumus sampel Issac dan Michael (Nursalam, 2014) dengan hasil 229 responden sudah termasuk dengan drop out.

Penelitian ini menggunakan instrumen penelitian yang berbentuk kuesioner. Kuesioner yang digunakan yaitu kuesioner Academic Stress Scale (ASS) dan Gastrointestinal Symptoms Rating Scale (GSRS). Kuesioner Academic Stress Scale (ASS) digunakan untuk mengetahui tingkat stres akademik yang dirasakan responden. Kuesioner ini terdiri dari 40 pertanyaan dengan lima hasil interpretasi yaitu tidak stres, stres ringan, stres sedang, stres berat, dan stres sangat berat. Hasil skor tertinggi menunjukkan bahwa tingkat stres akademiknya tinggi. Instrumen ini telah dilakukan uji validitas dan reliabilitas oleh Awaludin (2015), hasilnya pertanyaan valid dengan $(0,361-0,603)$ dan reliabel sangat tinggi $(r=0,963)$.

Kuesioner Gastrointestinal Symptoms Rating Scale (GSRS) digunakan untuk mengetahui gejala yang sering dialami oleh responden. Instrumen GSRS memiliki 15 pertanyaan untuk mengetahui gejala gastrointestinal yang sering dialami oleh responden yang diukur berdasarkan tingkat intensitas, frekuensi, dan durasi responden mengalami gejala gastrointestinal. Kuesioner GSRS menggunakan Skala Likert sebagai penilaian dengan tidak pernah untuk jawaban tidak merasakan gejala hingga selalu untuk jawaban merasakan gejala dalam waktu yang panjang yaitu merasakan gejala setiap hari, dan gejala menggangu aktivitas. Kuesioner ini dilakukan uji validitas dan reliabilitas terlebih dahulu sebelum digunakan. Hasil uji reliabilitas didapatkan nilai Cronbach alpha 0,750 . 
Selain mengidentifikasi stres akademik dan gejala gastrointestinal, peneliti juga mengidentifikasi karakteristik responden, seperti usia, jenis kelamin, tahun perkuliahan, waktu tinggal di kampus, indeks prestasi, dan jumlah kegiatan organisasi. Pengolahan data pada penelitian ini yaitu sebagai berikut: 1) Editing, proses memilah data yang lengkap dan drop out; 2) Coding, memberikan kode berdasarkan responden; 3) entry data, memasukkkan data ke dalam software statistik; 4) cleaning, memastikan data terbebas dari kesalahan.

Analisis data pada penelitian ini dibagi menjadi dua yaitu analisis univariat dan analisis bivariat. Analisis univariat bertujuan untuk mengetahui frekuensi dan proporsi dari karakteristik responden, sedangkan analisis bivariat untuk melihat hubungan antara kedua variabel tersebut. Variabel yang dimaksud yaitu variabel independen dan variabel dependen. Variabel independen pada penelitian ini yaitu tingkat stres dan variabel dependennya yaitu gejala gastrointestinal. Menggunakan uji Chi-square

\section{HASIL}

\section{Karakteristik responden}

Rentang usia responden pada penelitian ini yaitu 17-23 tahun dengan rata-rata usia 19,92 tahun (Tabel 1).

Tabel 1.

Karakteristik Responden (Usia) $(\mathrm{n}=227)$

\begin{tabular}{ccccc}
\hline Variabel & Mean & Median & SD & Min - max \\
\hline Usia & 19,92 & 20 & 1,272 & $17-23$ \\
\hline
\end{tabular}

Responden berjumlah 227 orang yang berasal dari empat angkatan sarjana reguler Fakultas Ilmu Keperawatan Universitas Indonesia. Jumlah responden perempuan lebih banyak dari laki-laki yaitu 214 (94,3\%). Pada bagian tahun perkuliahan hanya mahasiswa tahun ke 1 dan ke 3 yang sesuai dengan jumlah sampel yang sudah diperhitungkan pada pengambilan jumlah sampel dari populasi tiap angkatan mahasiswa S1 reguler FIK UI yaitu berjumlah
$60(26,4 \%)$ dan $56(24,7 \%)$ mahasiswa. Jumlah waktu mahasiswa tinggal di Kampus paling banyak yaitu 6-8 jam/ hari dengan jumlah 88 $(38,8 \%)$ mahasiswa. Mayoritas Indeks Prestasi (IP) semester terakhir mahasiswa yang menjadi responden yaitu IP dengan kategori baik $(2,76-3,50)$ berjumlah $178 \quad(78,4 \%) .94$ $(41,4 \%)$ responden memiliki 1 kegiatan organisasi (Tabel 2).

Tabel 2.

Karakteristik Responden $(n=227)$

\begin{tabular}{lcc}
\hline \multicolumn{1}{c}{ Karakteristik } & $\mathrm{f}$ & $\%$ \\
\hline Jenis kelamin & 13 & 5,7 \\
$-\quad$ Laki-laki & 214 & 94,3 \\
$-\quad$ Perempuan & & \\
\hline Tahun Perkuliahan & 60 & 26,4 \\
$-\quad$ Tahun ke-1 & 56 & 24,7 \\
$-\quad$ Tahun ke-2 & 56 & 24,7 \\
$-\quad$ Tahun ke-3 & 55 & 24,2 \\
$-\quad$ Tahun ke-4 & & \\
\hline Waktu Tinggal di Kampus & 18 & 7,9 \\
$-\quad \leq 3$ jam/ hari & 51 & 22,5 \\
$-\quad 4-6$ jam/ hari & 88 & 38,8 \\
$-\quad 6-8$ jam/ hari & 70 & 30,8 \\
$-\quad 8$ jam/ hari & & \\
\hline Indeks Prestassi & 2 & 0,9 \\
$-\quad 2,00-2,75$ & 178 & 78,4 \\
$-\quad 2,76-3,50$ & 47 & 20,7 \\
\hline
\end{tabular}


Tingkat Stres Akademik

Kategori stres dibagi menjadi 2 yaitu stres rendah (stres ringan dan stres sedang) dan stres berat (stres berat dan stres sangat berat). Berdasarkan hasil identifikasi tabel 3 disimpulkan bahwa mahasiswa S1 Reguler
Fakultas Ilmu Keperawatan Universitas Indonesia (FIK UI) masih terdapat yang memiliki tingkat stres yang tinggi (stres berat dan stres sangat berat) yaitu berjumlah 102 $(44,9 \%)$ orang

Tabel 3.

Tingkat Stres Akademik(n=227)

\begin{tabular}{ccc} 
Tingkat Stres Akademik & $\mathrm{f}$ & $\%$ \\
\hline Rendah & 125 & 55,1 \\
Tinggi & 102 & 44,9 \\
\hline
\end{tabular}

\section{Prevalensi Gejala Gastrointestinal}

Gejala gastrointesitnal dibagi menjadi 2 yaitu gejala ringan (tidak pernah sampai kadangkadang mengalami) dan berat (sering dan selalu mengalami). Hasil yang di dapatkan yaiitu $151(66,5 \%)$ responden yang mengalami gejala ringan dan $76(33,5 \%)$ responden yang mengalami gejala berat (Tabel 4). Mayoritas responden mengalami gejala ringan pada nyeri perut, gejala pada esofageal, gejala pada dismotilitas atas, gejala pada usus, dan inkontinensia fekal. Bila dilihat pada komponen gejala gastrointestinal yang dialami, nyeri perut sebanyak $198(87,2 \%)$ mengalami gejala ringan dan sebanyak $29 \quad(12,8 \%)$ mengalami gejala berat. Gejala pada esofageal sebanyak $187 \quad(82,4 \%)$ mengalami gejala ringan dan $40(17,6 \%)$ mengalami gejala berat. Gejala dismotilitas atas sebanyak $122(53,7 \%)$ mengalami gejala ringan dan 104 (45,8\%) mengalami gejala berat. Gejala pada usus sebanyak $149(65,6)$ mengalai gejala ringan dan 78 (34,4) mengalami gejala berat. Selanjutnya terdapat $217(95,6 \%)$ mengalami gejala inkontenensia fekal ringan dan 10 $(4,4 \%)$ mengalami gejala inkontinensia berat (Tabel 5).

Tabel 4.

Prevalensi Gejala gastrointestinal $(n=227)$

\begin{tabular}{ccc}
\hline Gejala Gastrointestinal & $\mathrm{f}$ & $\%$ \\
\hline Ringan & 151 & 66,5 \\
Berat & 76 & 33,5 \\
\hline
\end{tabular}

Tabel 5.

Prevalensi Gejala gastrointestinal Berdasarkan Komponen Gejala Gastrointestinal $(n=227)$

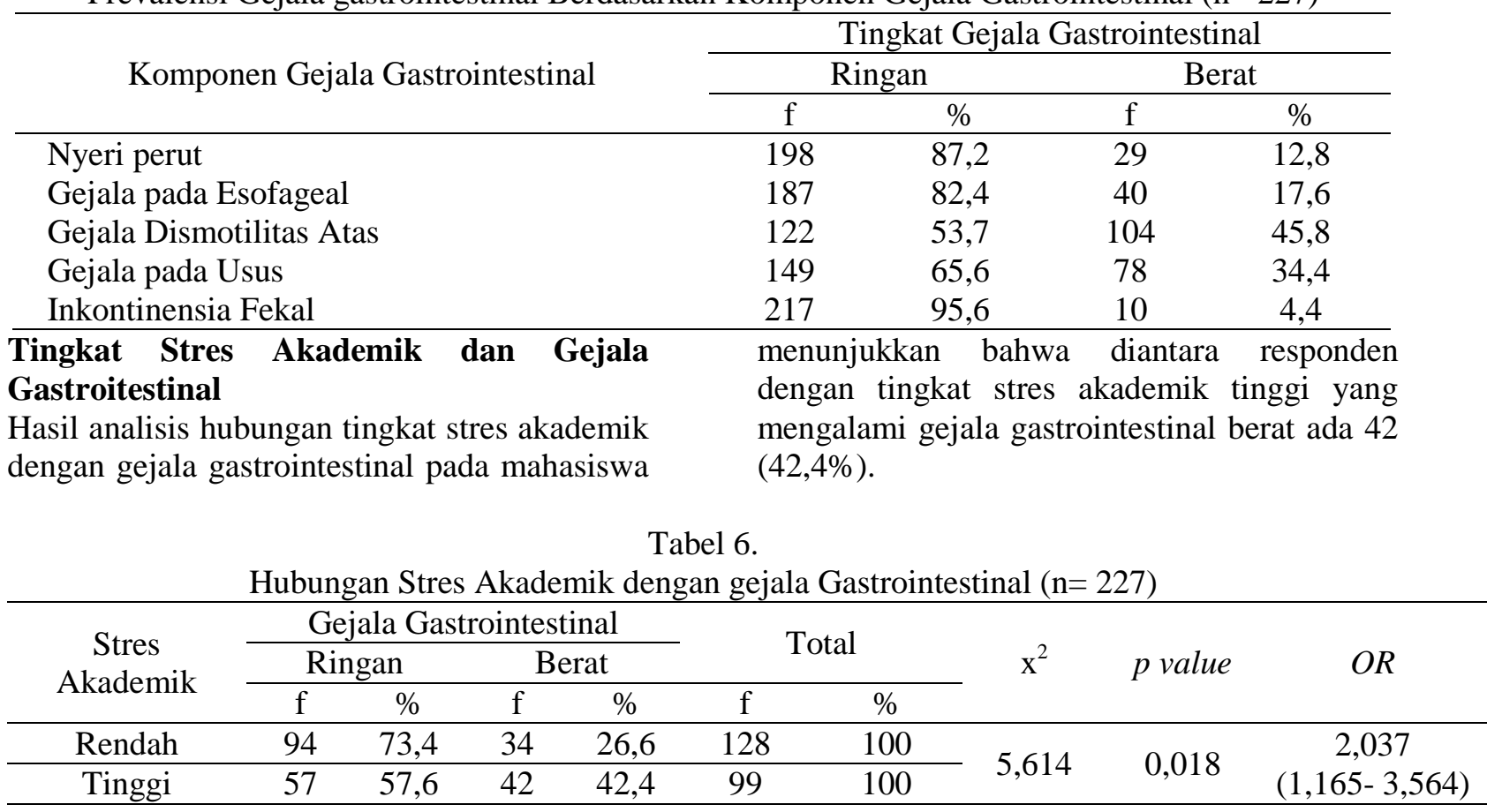


Hasil uji statistik didapatkan nilai $\mathrm{x}^{2}=5,641$ dan $p=0,018$, maka dapat disimpulkan ada perbedaan proporsi kejadian gejala gastrointestinal antara responden dengan stres akademik tinggi dan rendah (ada hubungan yang signifikan antara stres akademik dengan gejala gastrointestinal).

\section{PEMBAHASAN}

Berdasarkan hasil penelitian mayoritas responden stres tingkat rendah sebanyak $55,1 \%$. Tingkat stres rendah dalam penelitian ini merupakan gabungan antara stres ringan dan stres sedang. Hasil penelitian ini serupa dengan penelitian yang dilakukan oleh Sukmawati (2015) didapatkan hasil mayoritas mahasiswa FIK UI mengalami stres sedang sebanyak 93\%. Hasil yang berbeda terdapat pada penelitian yang dilakukan oleh Acharya \& Chalise (2015) pada 190 mahasiswa keperawatan di Khatmandu University hasilnya stres akademik yang paling banyak dialami yaitu stres tingkat tinggi sebesar $74 \%$.

Pada penelitian itu juga dijelaskan mahasiswa yang mengalami stres tingkat tinggi tersebut memiliki kondisi ekonomi dan pendidikan keluarga yang rendah, ditambah pula persepsi dukungan keluarga yang rendah. Perbedaan tingkat stres dapat terjadi karena tingkat stres lebih dipengaruhi oleh persepsi setiap individu terhadap stresor yang dialaminya. Hal tersebut pernah dikemukakan oleh Lazarus \& Folkman di tahun 1984 bahwa respon stres individu tergantung pada persepsi mengenai peristiwa yang sedang dialaminya termasuk ke dalam kategori tantangan atau ancaman. Maka dari itu pandangan seseorang terhadap stres mempengaruhi tingkat stresnya. Berdasarkan penjelasan ini, hal yang mempengaruhi perbedaan tingkat stres mahasiswa ialah persepsi stres pada setiap mahasiswa.

Tingkat stres ringan biasa terjadi pada setiap individu dan berlangsung selama beberapa menit atau jam dan tidak menimbulkan penyakit atau gangguan kecuali bila terjadi secara terus-menerus (Suzanne \& Brenda, 2008). Pada stres tingkat ini, individu akan merasa tenang saat stres telah berakhir. Selanjutnya pada tingkat stres akademik sedang, individu menjadi cenderung mudah emosi dan tidak fokus. Hal tersebut dapat mengganggu aktivitas akademik (Psychology Foundation of Australia, 2010). Selain itu, stres sedang dapat menjadikan individu memiliki efek psikologis seperti terganggunya kesehatan mental, emosi menjadi labil, hingga menyebabkan depresi (Glozah \& pevalin, 2014). Selain efek psikologis, efek fisiologis pun akan terganggu, salah satunya pada gejala gastrointestinal.

Hasil penelitian di dapatkan bahwa sebagian besar responden mengalami gejala gastrointestinal ringan yaitu sebanyak 151 orang $(66,5 \%), \quad$ Berdasarkarkan hasil identifikasi gejala per komponen dilaporkan bahwa gelaja berat yang paling banyak dialami yaitu gejala dismotilitas atas sebesar 45,8\%. Gejala ringan pada penelitian ini diartikan bahwa responden merasakan gejala 1-2 kali setiap minggunya (kadang-kadang).

Hasil penelitian ini di dukung oleh penelitian sebelumnya, seperti penelitian yang dilakukan di Canadian University hasilnya $51,2 \%$ dari 127 mahasiswa mengalami gejala gastrointestinal dan di University Switzerland 64,2\% dari 668 mahasiswa mengalami gejala gastrointestinal (Suarez, Mayer, Ehlert, Nater, 2010). Ditambah lagi, dilaporkan pada mahasiswa keperawatan korea di akademik keperawatan korea, gejala gastrointestinal yang sering dialami yaitu gejala dismotilitas atas dan gejala pada usus.

Gejala gastrointestinal yang terjadi merupakan hasil kombinasi dari faktor-faktor yang mengakibatkan perubahan motilitas usus, sensitifitas saraf usus yang meningkat, dan disregulasi interaksi antara otak dan usus. Faktor-faktor tersebut dapat dipengaruhi oleh pengaruh psikologis dan sosial (International Foundation for Functional Gastrointestinal Disorder, 2009; Kumar \& Clark, 2012). Faktor penyebab lain dapat dipengaruhi oleh kebiasaan tidur, makan yang buruk, diet, olahraga, faktor gaya hidup, serta stres yang berlebihan (Miwa, 2012). Dampak dari adanya gejala gastrointestinal yang dialami yaitu penurunan kualitas hidup yang dirasakan. Saat dilakukan uji statistik Chi-Square, peneliti menemukan adanya hubungan yang signifikan antara stres akademik dengan gejala gastrointestinal. Selain itu, responden dengan tingkat stres tinggi berpeluang 2,037 kali dapat mengalami gejala gastrointestinal dibandingkan dengan yang stres ringan.

Hasil yang sama terdapat pada penelitian yang dilakukan oleh Lee, Mun, Lee, \& Cho (2011) pada mahasiswa akademik keperawatan di Korea mengenai persepsi stres dengan gejala gastrointestinal menggunakan desain cross 
sectional dengan uji logistic regression mendapatkan nilai $p$ value $=0,00$ menunjukkan ada hubungan antara persepsi stres dengan gejala gastrointestinal yang dialami. Di tujuh universitas di Inggris, Wales, Irlandia Utara salah satu keluhan yang di alami berhubungan persepsi stres iala gejala gastrointestinal. Gejala gastrointestinal yang dari kadang-kadang hingga selalu dialami yaitu diare $(50,2 \%)$, konstipasi $(42,5 \%)$, heartburn $(70,6 \%)$, dan masalah perut lainnya $(49,8 \%)$. Penelitian ini dilakukan kepada 3.706 mahasiswa (Ansari, Oskrochi, Stock, 2013)

Di Eropa dilaporkan bahwa pada mahasiswa memiliki tingkat stres psikososial yang tinggi lebih mungkin mengalami keluhan psikosomatik (OR 2.32; CI 1.86-2.89) termasuk sakit leher dan sakit punggung (OR 1.34; CI 1.08-1.66) dan juga keluhan gastrointestinal (OR 1.39; CI 1.12-1.71) (Stock, et al., 2003). Penelitian lain di eropa menunjukkan bahwa gejala gastrointestinal secara signifikan memprediksi tingkat stres berat, disposisi keraktivan stres, dan menggunakan strategi koping yang maladaptif (Suarez, Mayer, Ehlert, Nater, 2010). Gejala gastrointestinal dapat disebabkan oleh berbagai macam salah satunya karena stres. Menurut Drossman \& Swantkowski (2006), saat stres hal yang terjadi pada sistem pencernaan yaitu iskemia mukosa lambung, peningkatan asam lambung, mual, mual, radang usus, panas pada perut, meningkatkan motilitas pada esofagus, lambung, ususs kecil, dan usus besar. Disebutkan pula sumber dari dispepsia dan sindrom iritasi usus adalah faktor psikososial seperti kepribadian dan stres kehidupan. Hal tersebut dapat membuktikan teori biospikososial, karena stres dapat memberikan pengaruh jangka pendek maupun jangka panjang terhadap fungsi dari saluran gastrointestinal (Bhatia \& Tandon, 2005). Stres dan emosi menjadi pemicu reaksi neuroimun atau neuroendokrin melalui "brain-gut axis" yang selanjutnya memengaruhi Gastrointestinal, endokrin, fungsi imun.

\section{SIMPULAN DAN SARAN Simpulan}

Bila melihat hasil penelitian dan penjelasan pada pembahasan dapat disimpulkan bahwa tingkat stres akademik pada mahasiswa tergantung pada persepsi mahasiswa dalam memandang masalah akademik yang dihadapi, tingkat stres akademik pada penelitian ini berada pada rentang stres ringan hingga stres sedang atau dalam penelitian ini dikategorikan menjadi tingkat stres rendah.

Gejala gastrointestinal dapat menjadi salah satu dampak yang dilaporkan sebagai akibat dari stres yang dialami. Hasil dari penelitian ini sebagian besar responden mengalami gejala gastrointestinal yang terjadi 1-3 kali per minggu dan belum menganggu aktivittas dari responden. Gejala gastrointestinal yang sering terjadi pada mahasiswa keperawatan Universitas Indonesia serupa dengan yang dilaporkan pada mahasiswa keperawatan di Korea. Gejala pada dismotilitas atas dan gejala pada usus merupakan gejala yang paling banyak dilaporkan.

\section{Saran}

Penelitian ini dapat digunakan untuk mengembangkan intervensi yang efektif dalam mengurangi stres pada mahasiswa. Selain itu hasil identifikasi dari penelitian ini dapat dijadikan informasi berharga untuk melakukan penelitian terkait stres dan respon fisiologisnya.

\section{DAFTAR PUSTAKA}

Esteem an Academic Stress among Nursing Student. Khatmandu Univ Med, 13 (52): 298-302.

Andri. (2011). The Biopsychosocial Concept in Psychosomatic Complaints. 61 (9). 375379.

Ansari, Walid El, Oskcrochi, Reza, Stock, Christiane. (2013). Symptoms and health complaints and their association with perceived stress: student from seven universities in England, Wales, and Northern Ireland. J public health 21: 413-425.

Awaludin, Ijang. (2015). Tingkat Stres Akademik pada Mahasiswa Penerima Program Beasiswa Pengembangan Diri (Beastudi Etos) Wilayah Jakarta dan Bogor (Skripsi). Universitas Indonesia, Depok, Jawa Barat.

Bathia, V, Tando, Rakesh K. (2005). Stres and the Gastrointestinal track. Journal of gastroenterology and Hepatology 20, 332-339.

Drossman, Douglas A. Swantkowski, Melissa. (2006) History of Functional Disorder. 
UNC Center for Functional GI and Motility Disorder.

Hurst, Carrie S., Baranik, Lisa E., Daniel, Francis. (2012). College Student Stressor: a review of the qualitative Research. John Wiley \& Sons, Ltd. http://onlinelibrary.wiley.com/doi/10.10 $\underline{02 / \mathrm{smi} .2465 / \text { full. }}$

International Foundation for Functional Gastrointestinal Disorder. (2009). Reporter's Guide to Functional Gastointestinal Disorders. Milwaukee: Medronic Foundation.

Lee, Y.E., Mun M.S., Lee, S.H., Cho H.S.M. (2011). Perceived stress and gastrointestinal symptoms in nursing student in Korea: A cross-sectional survey. 10 (22). 1-8.

Miwa, H. (2012). Life Style Persons with Functinal Gatrointestinal DisordersLarge-Scale Internet Survey of Lifesyle in Japan. Neurogastronterol Motil 24, 464-e217.

Nursalam. (2014). Metodologi Penelitian Ilmu Keperawatan: Pendekatan Praktis Edisi 3. Jakarta: Salemba Medika.

Psychology Foundation Of Australia. (2010). Depression Anxiety Sress Scale.

Http://Www2.Psy.Unsw.Edu.Au/Group/Dass.

Smeltzer, Suzanne C. (2008). Buku Ajar keperawatan Medikal Bedah Brunner \& Suddart. Editor oleh Suzanne C. Smeltzer, Brenda G, Bare, jakarta: EGC.

Smith, G.D., Watson, Roger. (2005). Gastrointestinal Nursing. USA: Blackweel Publishing.

Stuart, G.W \& Laraia, M.T (2005). Psychiatric nursing : Principle and practice 8th Edition. St. Louis : Mosby.

Suarez K, Mayer C, Ehlert U, Nater UM: Psychological stress and selfreported functional gastrointestinal disorders. $\mathbf{J}$ Nerv Ment Dis 2010, 198:226-9.

Sukmawati, Astri. (2015). Hubungan antara Kecerdasan dengan Tingkat Stres
Mahasiswa FIK UI (Skripsi).

Universitas Indonesia, Depok, Jawa Barat.

Suzanne \& Brenda. (2008). Text book of medical surgical nursing 11th ed. Philadelphia: Lippincott Williams \& Wilkins

Stock C, Kucuk N, Miseviciene I, GuillenGrima F, Petkeviciene J, AguinagaOntoso I, Kramer A. (2003). Differences in health complaints among university students from three European countries. Prev Med 2003, 37:535-43.

Wilks, S.E. (2008). Resilience amid academic stress: The moderating impact of social support among social work student: advances in social work, 9 (2), 106125.

https://journals.iupui.edu/indeks.php/ad vancesinsocialwork/article/viewFile/51/ $\underline{195}$ 